\title{
Penentuan Tingkat Kekumuhan Kawasan Permukiman Kelurahan Bhayangkara Distrik Jayapura Utara Kota Jayapura
}

\author{
Musfira \\ Fakultas Teknik Sipil dan Perencanaan, Universitas Sains dan Teknologi Jayapura \\ fira.naja3@@yahoo.com
}

\section{INFO ARTIKEL \\ Riwayat Artikel:}

Diterima: 6-6-2018

Disetujui: 20-7-2018

\section{Kata Kunci:}

Permukiman

kumuh

Kawasan

\begin{tabular}{l} 
INFO ARTIKEL \\
\hline Riwayat Artikel: \\
Diterima: 6-6-2018 \\
Disetujui: $20-7-2018$
\end{tabular}

\begin{abstract}
ABSTRAK
Abstrak: Penelitian ini bertujuan untuk mengetahui penaatan kawasan permukiman yang tepat untuk permukiman kumuh di Kelurahan Bhayangkara. Tujuan dari penelitian adalah mengetahui tingkat kekumuhan di kawasan permukiman Kelurahan Bhayangkara sehingga dapat ditentukan langkah penanganannya. Metode penelitian yang digunakan berupa metode kuantitatif dengan teknik analsis deskriptif dan pembobotan untuk menganalisis data yang dikumpulkan secara primer dan sekunder. Output yang dihasilkan pada penelitian ini adalah tingkat kekumuhan di kawasan permukiman Kelurahan Bhayangkara Distrik Jayapura Utara Kota Jayapura.
\end{abstract}

\begin{abstract}
This study aims to determine the compliance of residential areas that are right for slums in Bhayangkara Village. The purpose of the study was to find out the level of slum in the residential area of Bhayangkara Village so that steps can be determined. The research method used is a quantitative method with descriptive and weighting analysis techniques to analyze data collected in primary and secondary. The output produced in this study is the level of slum in the residential area of Bhayangkara District, North Jayapura District, Jayapura City.
\end{abstract}

\section{A. LATAR BELAKANG}

Kota Jayapura berdasarkan status dan fungsinya adalah merupakan kawasan pusat pengembangan kegiatan perdagangan, perkantoran dan jasa dengan lingkup pelayanan seluruh wilayah Propinsi dan Kota, yang mana juga memiliki daya sentrifugal dari aspek keruangan yaitu salah satunya adalah aspek penduduk. Laju pertumbuhan penduduk Kota Jayapura dengan status dan latar belakang yang heterogen menyebabkan adanya kosentrasi pada beberapa kawasan pemukiman. Kawasan pemukiman yang diindikasikan terjadi adanya kosentrasi penduduk yang tinggi, salah satunya adalah di Kelurahan Bhayangkara Distrik Jayapura Utara.

Kelurahan Bhayangkara merupakan salah satu kelurahan yang terdapat di Distrik Jayapura Utara dengan luas mencapai $\pm 194 \mathrm{Ha}$, yang terdiri dari $7 \mathrm{RW}$ dan 38 RT. Berdasarkan Rencana Tata Ruang Wilayah (RTRW), kawasan Kelurahan Bhayangkara umumnya didominasi oleh peruntukan perumahan dan pemukiman dengan luas lebih kurang 3.746 Ha yang sudah terbangun 92,8 Ha. perbukitan dan hutan konservasi, pusat pemerintahan, perdagangan dan jasa serta perkantoran. Kondisi tersebut oleh masyarakat dimanfaatkan untuk membuka lahan pemukiman, pada beberapa titik kawasan dengan mempertimbangkan kemudahan aksesbilitas dan mobilitas masyarakat itu sendiri.

Namun pada kenyataannya dengan seiring meningkatnya pembangunan dan jumlah penduduk pada 3 tahun terakhir yaitu pada tahun 2016 sebesar
11.306 jiwa, pada tahun 2017 sebesar 11.535 jiwa dan pada tahun 2018 meningkat 1.351 jiwa atau mencapai sebesar 12.886 jiwa dengan jumlah kepala keluarga yang mencapai 5.3021 KK. Dengan demikian kebutuhan akan lahan pemukiman semakin meningkat dan hal terebut akan mempengaruhi beberapa factor yang mempengaruhi kualitas pemukiman seperti kerapatan bangunan, ketersediaan sarana dan prasaran dasar permukiman kondisi lingkungan dan sebagainya.Kondisi permukiman saat ini satu perumahan yang layaknya hanya dihuni $1 \mathrm{KK}$ atau 5 orang namun yang terjadi di kawasan pemukiman di Kelurahan Bhayangakara dalam 1 rumah dihuni oleh 6 sampai 7 orang. Hal tersebut berdampak pada pembangunan mengarah ke hutan konservasi dan badan sungai.

Adapun sumber mata pencaharian atau pekerjaan masyarakat di Kelurahan Bhayangakara lebih didominasi oleh sektor swasta dan PNS. Rata-rata jumlah pendapatan masyarakat per bulan berkisar antara Rp. 500.000,- sampai Rp. 5.000.000,-. Dengan tingkat pendapatan masyarakat yang sebagian masih tergolong rendah menyebabkan masyarakat kesulitan untuk membenahi tempat tinggal rumah mereka.

Kelurahan Bhayangkara yang sebagian besar adalah kawasan perbukitan dan hutan konservasi maka terjadinya penurunan debit air, erosi di kawsan tersebut. Indikasi lain dari permasalahan lingkungan pemukiman di Kelurahan Bhayangkara adalah kurangnya tingkat 
kesadaran masyarakat, lingkungan pemukiman kotor dan kurangnya fasilitas penunjang yang layak.

Permasalahan yang sering dihadapi kota sejalan dengan perkembangan kota adalah tingkat kepadatan akan lahan, perkembangan lahan kota bukan hanya sebagai tempat pembangunan tetapi juga merupakan tempat interaksi masyarakat. Keterbatasan akan lahan ini secara umum hampir disetiap kota-kota besar dikarenakan semakin bertambahnya jumlah penduduk yang mendiami kota sehingga tata guna lahan kota sering menjadi acuan walaupun ini juga sering menjadi masalah karena perkembangan kota tidak sejalan dengan perkembangannya.

Berdasarkan target Pemerintah Kota Jayapura bahwa tahun 2019 akan membuat Kota Jayapura sebagai lingkungan permukiman di perkotaan bebas akan lokasi kumuh.

Seiring dengan meningkatnya kebutuhan lahan akan penyediaan rumah atau pemukiman menyebabkan adanya konsentrasi penduduk pada beberapa titik di Kelurahan Bhayangkara yang menimbulkan pola keruangan pemukiman yang tidak teratur dan tertata dengan baik. Peningkatan kebutuhan pada akhirnya menyebabkan pembangunan mulai merambah ke arah perbukitan karena keterbatasan lahan di Kelurahan Bhayangkara. Berdasarkan arahan tata ruang Kota Jayapura daerah perbukitan tersebut direkomendasikan sebagai hutan lindung sekaligus penyangga bagi Kota Jayapura. Sehingga hal ini bertentangan dengan tata ruang kota dan juga mempengaruhi optimalisasi pemanfaatan ruang terbuka, tata guna lahan dan menurunnya kualitas ruang serta ancaman akan bahaya yang akan ditimbulkan.

Penelitian ini bertujuan untuk menganalisis tingkat kekumuhan kawasan permukiman di Kelurahan Bhayangkara Kota Jayapura guna peningkatan pengawasan rencana pemanfaatan ruang yang sesuai dengan aktifitas pembangunan melalui keterpaduan perencanaan yang serasi, selaras, seimbang dan berkesinambungan.

\section{B. METODE PENELITIAN}

Penelitian ini menggunakan metode deskriptif, dimana penyelidikan deskriptif tertuju pada pemecahan masalah pada masa sekarang. Metode deskriptif yang dilakukan adalah representasi objektif terhadap fenomena dan permasalahan yang diperolah pada lokasi studi. Pelaksanaan metode deskriptif tidak terbatas hanya sampai pengumpulan dan penyusunan data saja, tetapi juga meliputi analisa dan pengolahan data. Sedangkan teknik penelitian dimulai dengan pengumpulan data yang dilakukan melalui survey dan observasi langsung pada lokasi studi namun pada tahapan sebelumnya dilakukan dengan studi pustaka sebagai pemahaman teoritis. Dari data yang diperoleh, dilakukan analisis terhadap kondisi rill di wilayah studi yang mana lokasinya bertempat pada kawasan permukiman di Kelurahan Bhayangkara Distrik Jayapura Utara.

\section{HASIL DAN PEMBAHASAN \\ 1. Identifikasi Kondisi Eksisiting Wilayah Studi}

\section{a. Kependudukan}

Penduduk merupakan subjek dan objek pembangunan yang juga sebagai sumber utama dalam pelaksanaan kegiatan pembangunan, penduduk juga berfungsi sebagai pendorong suksesnya perkembangan suatu kota. Secara keseluruhan jumlah penduduk Kelurahan Bhayangkara pada awal tahun 2018 adalah berjumlah 12.886 jiwa, dimana penduduk laki-laki berjumlah 6.508 jiwa dan penduduk perempuan sebanyak 6.828 jiwa dengan jumlah kepala keluarga mencapai 5.3021 KK. Umumnya pendataan penduduk ditiap RT pada masingmasing RW susah untuk dilakukan, karena banyaknya penduduk yang tidak tetap atau berpindah-pindah dari rumah sewa/kos-kosan satu ke rumah sewa/kos-kosan yang lain baik masih di Kelurahan Bhayangkara ataupun di luar Kelurahan Bhayangkara.

Sebagian besar warga Kelurahan Bhayangkara bermata pencaharian sebagai pegawai negeri sipil (PNS) yaitu sebanyak 884 orang, sedangkan mata pencaharian sebagai nelayan 27 orang, TNI-Polri 240 orang, petani atau pekebun 15 orang, pertukangan 30 orang, swasta 2.084, wiraswasta atau pedagang 320, jasa 164 orang, dan pensiunan sebanyak 190 orang.

\section{b. Sarana Prasarana}

1) Kesehatan

Pada umumnya jumlah fasilitas kesehatan yang terdapat di Kelurahan Bhayangkara sudahlah cukup memadai, dimana terdapat 1 unit RS, 1 unit puskesmas, 1 unit pustu dan 7 unit posyandu yang merata tersebar di tiap RW. Secara umum kondisi kesehatan masyarakat di Kelurahan Bhayangkara belum dapat dikatakan baik atau meningkat, karena pada umumnya tingkat kesadaran masyarakat itu sendiri yang masih kurang. Hal ini terbukti dengan keadaan lingkungan yang kotor dan dipenuhi oleh sampah.

2) Peribadatan

Jumlah fasilitas peribadatan di Kelurahan Bhayangkara adalah gereja 6 unit, mesjid 8 unit, dan belum terdadatnya pura serta vihara.

3) Perekonomian

Umumnya fasilitas penunjang perekonomian di Kelurahan Bhayangkara sudah dapat dikatakan cukup memadai.

Hal ini dapat dilihat dari jumlah fasilitas perdagangan dan jasa yang cukup guna memenuhi kebutuhan masyarakat pada tingkat RW dan RT yang terdapat di Kelurahan Bhayangkara. Jumlah fasilitas perdagangan dan jasa yang terdapat di Kelurahan Bhayangkara yaitu toko sebanyak 2 unit, minimarket sebanyak 1 unit, toko kelontong sebanyak 100 unit, restoran sebanyak 20 unit, 
kedai makanan 50 unit, hotel sebanyak 2 unit, pasar semi permanen dan permanen berjumlah 2 unit serta pasar tidak permanen berjumlah 2 unit.

4) Jaringan Jalan

Jalan merupakan salah satu sarana prasarana transportasi yang penting guna memeperlancar aktifitas dan mobilitas penduduk di kawasan Kelurahan Bhayangkara. Umumnya prasarana jalan di kawasan studi sudah sangat memadai, dimana prasarana ini dapat dilalui oleh kendaraan roda dua (2) maupun roda empat (4). Untuk kondisi jalan utama di Kelurahan Bhayangkara dari segi kondisi tidak terdapat permasalahan karena sudah diaspal dan lebarnya sudah sesuai standar.

\section{5) Jaringan Drainase}

Drainase yang terdapat pada Kelurahan Bhayangkara adalah saluran drainase terbuka yang terdapat pada permukiman warga sedangkan drainase tertutup dapat dijumpai pada jalan-jalan protokol dilokasi studi. Drainase yang terdapat pada lokasi studi banyak yang dipenuhi oleh sampah yang menyumbat saluran drainase tersebut, hal ini disebabkan oleh kurangnya kesadaran masyarakat yang membuang sampah sembarangan.

Drainase pada lokasi studi ini dapat diklasifikasikan dalam 2 jenis yaitu drainase permanen dan non permanen. Drainase permanen umumnya berada di jalan utama dengan ukuran lebar $20-90 \mathrm{~cm}$ dan kedalaman 50-100 cm sedangkan drainase disekitar permukiman penduduk yaitu drainase non-permanen dengan lebar rata-rata $20-50 \mathrm{~cm}$ dan kedalamannya $5-20 \mathrm{~cm}$.

\section{6) Air Bersih}

Sumber air baku di Kelurahan Bhayangkara berasal dari sungai APO dan suplai dari sub-sistem Kujabu. Intake pada sungai apo sebanya 2 buah dengan debit 63 ltr/dt untuk melayani Masyarakat di RW I - RW IV dan 5 ltr/dt untuk mengaliri RW V - RW VII. Berdasarkan pemeriksaan laboratoriun kualitas air dari sumber ini sangat bagus untuk memenuhi syarat air minum. Dalam pengadaan penyediaan air bersih pada lokasi studi pada umunya masyarakat melakukannya secara swadaya, hal ini dapat dilihat karena umumnya air bersih dialiri melalui selang melalui mata air yang terdapat pada wilayah studi.

7) Perumahan

Rumah merupakan salah satu kebutuhan dasar manusia yang selain berfungsi sebagi sarana hunian juga berfungsi sebagai tempat untuk berinteraksi sosial antar keluarga. Berdasarkan hasil pengamatan visual setidaknya terdapat bangunan permanen sebanyak 1.306 unit, semi permanen sebanyak 1.881 unit dan tidak permanen sebanyak 2.298 unit (Sumber data : Distrik Jayapura Utara dalam angka 2018).
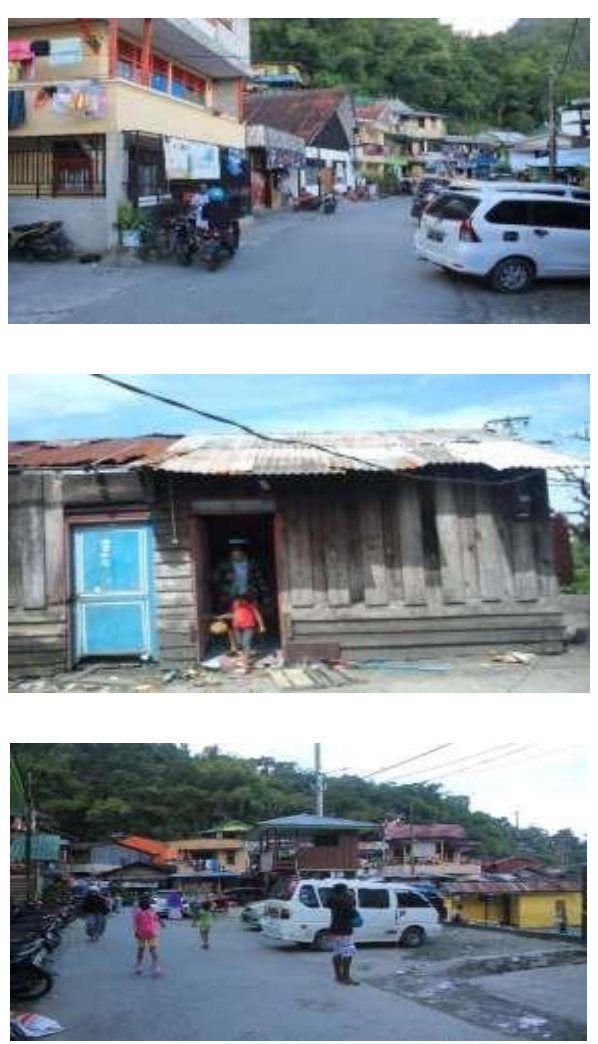

Gambar 1. Kondisi Pemukiman

Kondisi esksiting di Kelurahan Bhayangakara menurut beberapa warga yang sudah bermukim hampir 20 tahun terbentuknya permukiman di Kelurahan Bhayangkara ini akibat harga tanah yg murah dan dekat dengan pusat kota dan perdagangan dan jasa. Hal tersebut yang menajdi alasan mengapa masyarakat membeli tanah dan bermukim disana sedangkan berdasarkan arahan tata ruang wilayah Kelurahan Bhayangkara sudah di peruntukkan sebagai hutan konservasi.

Hasil observasi di lapangan secara langsung yang dilihat kondisi bangunan yang kurang baik dan kurangnya fasilitas yang baik seperti MCK (toilet umum) yang hanya 23 unit yang sedangkan yang masih digunakan sampai saat ini hanya 18 unit saja sedangkan 5 unit sudah tidak dapat dipergunakan lagi karena sudah rusak atau tidak terurus lagi. Masayarakat di Kelurahan Bhayangkara menggunakan MCK secara bersama-sama dimana 2 rumah menggunakan satu MCK di tiap-tiap rumah. Kuliatas hunian yang ada di beberapa RW yaitu semi permanen dan non permanen fasilitas lain seperti drainase yang kurang baik, seta jalan-jalan lingkungan yang rusak dan kondisi persampahan yang dibuang langsung ke sungai mengakibakan penumpukan sampah, dan kondisi lingkungan yang tidak sedap dipandang dan mengganggu kesehatan masyarakat Kelurahan Bhayangkara.

\section{Analisis Tingkat Kekumuhan}

\section{a. Tingkat Kepadatan Penduduk}

Berdasarkan tingkat kepadatan penduduk, maka beberapa kawasan permukiman memiliki kategori penilaian yang berbeda, kepadatan penduduk tertinggi 
terdapat pada RW 03 dan RW 04 dengan tingkat kepadatan mencapai \pm 74 jiwa/ha. Jika dilakukan dilakukan cross check dengan klasifikasi indikator permukiman kumuh, maka keseluruhan dari Kelurahan Bhayangkara dikategorikan kedalam permukiman yang masih memiliki prioritas dalam pengembangan perumahan dan permukiman. Lebih jelasnya untuk tingkat kepadatan penduduk, dapat dilihat pada tabel berikut:

Tabel 1.

Kepadatan Penduduk/RW

\begin{tabular}{|c|c|c|c|c|c|c|c|}
\hline \multirow{2}{*}{ Dermatimas } & \multicolumn{3}{|c|}{ Jumbla Prodedat: (Jima) } & \multirow{2}{*}{$\begin{array}{c}\text { Laas } \\
\text { weyas }\end{array}$} & \multicolumn{3}{|c|}{ Kepetatas (0ma/an) } \\
\hline & 2013 & 2016 & 265 & & 2013 & 2616 & 2020 \\
\hline RW: : & 1.258 & 1312 & 1339 & 29.15 & 44.53 & 45.08 & 45,93 \\
\hline $\mathrm{RW}=$ & 1502 & 1531 & 1573 & 26,45 & 58,72 & 57,82 & 59,40 \\
\hline RW 3 & 1974 & 1996 & 2057 & 27.6 & 71.52 & 2232 & 74.53 \\
\hline RW 4 & 1952 & 1999 & 2072 & 28.13 & 69,39 & $7.0 s$ & 73,60 \\
\hline RW 5 & 1536 & $15 \%$ & 1042 & 273 & $\$ 8,26$ & 58.02 & $\infty, 15$ \\
\hline RW & 1.488 & 1.495 & 1529 & 27,14 & 54,69 & 55,08 & 56,34 \\
\hline RW 7 & 1576 & 1.589 & 1611 & 28.2 & 55,87 & 56,35 & 57,13 \\
\hline JMLAH & 11.306 & 11.595 & 11.523 & 154 & ss, 2s & 90,46 & $\infty, 9$ \\
\hline
\end{tabular}

Sumber: Hasil Analisa

\section{b. Tingkat Pertumbuhan Penduduk}

Zonasi lahan berdasarkan tingkat pertumbuhan penduduk dengan ketentuan pertumbuhan penduduk >2,5 \% diikategorikan sangat kumuh. Dari ketentuan tersebut unit permukiman yang dikategorikan sangat kumuh terdapat pada RW II, III, IV dan RW V. Kategori kumuh berat terdapat pada RW VI. Kategori kumuh sedang terdapat pada RW I dan RW VII

c. Kualitas Bangunan

Penilaian terhadap kualitas bangunan yang dimaksud adalah kondisi dari suatu bangunan dalam memberi jaminan kenyamanan bagi penghuninya, penilaian yang dilakukan terhadap kondisi dan kualitas bangunan hunian di Kelurahan Bhayangkara dapat diklasifikasikan dengan cara mengkondisikan bangunan menurut pengklasifikasian secara baik, sedang, dan buruk. Dari hasil perhitungan tersebut jika dilakukan zonasi kawasan maka, permukiman Kelurahan Bhayangkara digolongkan dalam permukiman kumuh ringan. Sedangkan jika ditinjau secara mikro maka, unit permukiman RW 03 dan RW 04 merupakan kawasan permukiman kumuh sedang dengan besarnya persentase kondisi bangunan buruk mencapai $30-33 \%$.

Tabel 2.

Penilaian Kondisi Kualitas Bangunan Pada Kelurahan Bhayangkara

\begin{tabular}{|c|c|c|c|c|c|c|c|}
\hline \multirow{2}{*}{$\begin{array}{c}\text { V'nit } \\
\text { L.ingkuangan } \\
\text { Permukiman }\end{array}$} & \multicolumn{3}{|c|}{ Kondisi Bangunan } & \multirow{2}{*}{ Jamiab } & \multicolumn{3}{|c|}{ Persentase \% } \\
\hline & Baik & Sedang & Buruk: & & Batk: & Sedang & Buruk \\
\hline RW01 & 127 & 471 & 118 & 316 & 17,74 & 65,75 & 16,48 \\
\hline $\mathrm{RWO2}^{2}$ & 131 & 496 & 154 & 781 & 16,77 & 3,51 & 19,72 \\
\hline RW 03 & 116 & 402 & 255 & 773 & 15,01 & 52 & 32,99 \\
\hline $2 W 04$ & 97 & 559 & 283 & 939 & 10.33 & 59.53 & 30.14 \\
\hline RW0S & 149 & 455 & 111 & 745 & 20 & 65,10 & 14,90 \\
\hline RW: DS & $1+2$ & 524 & $\$ 6$ & 752 & 18,89 & 69,68 & 11,43 \\
\hline RWO? & 164 & 537 & 78 & 779 & 21,05 & 68,93 & 10,02 \\
\hline Jumba & 926 & 3.474 & 1.055 & 5.485 & $16.5 \mathrm{~s}$ & 63,34 & 19.78 \\
\hline
\end{tabular}

Sumber: Hasil Analisa

\section{d. Kepadatan Bangunan}

Pada dasarnya perhitungan terhadap tingkat kepadatan bangunan adalah untuk mengetahui perbandingan antara banyaknya bangunan hunian dengan lahan yang tersedia. Menurut perhitungan yang dilakukan, tingkat kepadatan bangunan hunian permukiman secara makro pada lokasi studi adalah sebanyak 28 unit/ha dan kepadatan bangunan tertinggi jika dilihat menurut ruang lingkup mikronya terdapat pada RW 04 yang mencapai 33 unit/ha.

Tabel 3.

Kepadatan Bangunan

\begin{tabular}{|c|c|c|c|}
\hline $\begin{array}{c}\text { Cnit } \\
\text { Permukiman }\end{array}$ & $\begin{array}{c}\text { Jumlah } \\
\text { Bangunan (Unit) }\end{array}$ & $\begin{array}{c}\text { Luas Wilayah } \\
\text { (Ha) }\end{array}$ & $\begin{array}{c}\text { Kepadatan } \\
\text { Banguman } \\
\text { (Unit/Ha) }\end{array}$ \\
\hline RW 01 & 716 & 29,15 & 24,56 \\
\hline RW 02 & 781 & 26,48 & 29,50 \\
\hline RW 03 & 773 & 27,6 & 28 \\
\hline RW 04 & 939 & 28,13 & 33,38 \\
\hline RW05 & 745 & 27,3 & 27,29 \\
\hline RW 06 & 752 & 27,14 & 27,71 \\
\hline RW 07 & 779 & 28,2 & 27,62 \\
\hline Jumlah & $\mathbf{5 . 4 8 5}$ & $\mathbf{1 9 4}$ & $\mathbf{2 8 , 2 7}$ \\
\hline
\end{tabular}

Sumber : Hasil Analisa

\section{e. Legalitas Tanah}

Legalitas tanah pada unit-unit permukiman Kelurahan Bhayangkara secara unit lingkungan permukimannya dengan persentase tertinggi terdapat pada RW 04 yang mencapai 42,86 \% dan RW o1 yang mencapai 30,77 \%, secara keseluruhan terdapat 22,45 \% bangunan belum dilengkapi aspek legal. Prosentase demikian jika disesuaikan dengan standarisasi permukiman, maka permukiman di Kelurahan Bhayangkara dapat dikategorikan sebagai kawasan kumuh ringan tapi jika dilihat dari unit permukimannya maka RW 04 dan RW 01 merupakan kawasan kumuh sedang.

Tabel 4.

Status Legalitas Tanah

\begin{tabular}{|c|c|c|c|c|c|}
\hline \multirow{2}{*}{$\begin{array}{c}\text { Vnit } \\
\text { Linqkungan } \\
\text { Permuldman }\end{array}$} & \multicolumn{2}{|c|}{ States Legalitas Banguasa } & \multirow[b]{2}{*}{ Jumlah } & \multicolumn{2}{|c|}{ Presentase * } \\
\hline & Bersertifukat & $\begin{array}{c}\text { Tidak } \\
\text { Bersertinikat }\end{array}$ & & Bersertifakat & $\begin{array}{c}\text { Tidak } \\
\text { Bersertinkat }\end{array}$ \\
\hline RW01 & 9 & 4 & 13 & 69,23 & 30,77 \\
\hline RW02 & 12 & 2 & 14 & 85.71 & 14,29 \\
\hline RW 03 & 8 & 6 & 14 & 57.14 & 42.86 \\
\hline RW04 & 12 & 5 & 17 & 70,58 & 29,42 \\
\hline RWOS & 12 & 1 & 13 & 92,31 & 7,69 \\
\hline RW06 & 10 & 3 & 13 & 76,92 & 23,08 \\
\hline RW 07 & 13 & 1 & 14 & 92,56 & 7,14 \\
\hline Jumblah & 76 & 22 & 98 & 77,55 & 22,45 \\
\hline
\end{tabular}

Sumber: Hasil Analisa

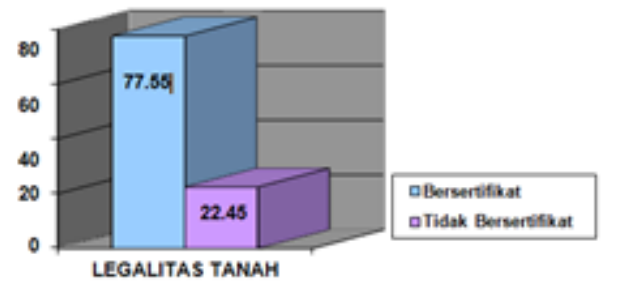

Gambar 2. Grafik Status Legalitas Tanah 
Dari tabel dan grafik terlihat dengan jelas bahwa aspek legalitas pada permukiman Kelurahan Bhayangkara terutama pada beberapaa titik kawasan pada tingkatan RT perlu ditinjau kembali agar pada kemudian hari tidak menimbulkan masalah dalam penanganannya. Permasalahan legalitas tanah ini merupakan kepentingan umum sehingga penanganan oleh pemerintah sangat diperlukan.

f. Kondisi Sanitasi Lingkungan

Dari ketentuan besaran indikator permukiman, jika dilakukan perbandingan terhadap fasilitas pengelolaan limbah rumah tangga pada Kelurahan Bhayangkara, maka secara keseluruhan telah tersedia. Hal ini berarti kawasan unit permukiman pada Kelurahan Bhayangkara dikategorikan ke dalam kawasan kumuh sedang dan ini berdasarkan pengamatan secara langsung pada kondisi permukiman.

\section{g. Hasil Penilaian Terhadap Zonasi Lahan}

Dari hasil identifikasi kondisi eksisting dan analisa terhadap indikator-indikator yang berfungsi untuk zonasi lahan atau pun kawasan yang telah dibahas di atas, maka dapat disimpulkan penilaian terhadap pengklasifikasian permukiman di Kelurahan Bhayangkara perlu mendapatkan rehabilitasi terhadap kawasan permukiman pada tiap-tiap unit lingkungannya.

\section{Tabel 5.}

Hasil Penilaian Terhadap Zonasi Lahan Berdasarkan

\begin{tabular}{|c|c|c|c|c|c|c|c|}
\hline \multirow{2}{*}{ Indikater Penilaian } & \multicolumn{7}{|c|}{ 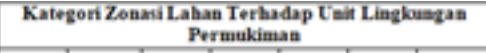 } \\
\hline & RW 1 & RW 2 & RW 3 & RW 4 & RW 5 & RW6 & RW 7 \\
\hline Kepadatis pendoduk & $\operatorname{xxx\times x}$ & Xxxxx & $x \times x \times x$ & $x \times x x x$ & $\mathbf{x x x x x}$ & $\mathbf{x x x x x}$ & Xxux \\
\hline Pertumbuhas pendudek & $\mathbf{x x x}$ & $\mathrm{x}$ & $\mathrm{x}$ & $\mathrm{x}$ & $\mathrm{x}$ & $\mathrm{xx}$ & $\mathrm{Xxx}$ \\
\hline Kealitas banganan & $x x x x$ & Xexex & $\mathbf{x x x}$ & $x \times x$ & $\operatorname{xxx}$ & 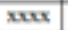 & Xoxux \\
\hline Kepadatan bangunan & $\mathbf{x x x x x}$ & Xxxxx & $\mathbf{x x x x}$ & $\mathbf{x x x x x}$ & $\mathbf{x x x x x}$ & $\mathbf{x x x x x}$ & Xxuxx \\
\hline Legalitas unzh & $\mathbf{x x x}$ & Xax & $\mathbf{x x x}$ & $\mathbf{x x x x}$ & $\mathbf{x x x x x}$ & $x \times 0 x$ & Xxux \\
\hline Kondisis sanitasi & $\mathbf{x x x x}$ & Xox & $\mathbf{x x x x}$ & $\mathbf{x x x x}$ & $200 x$ & 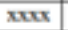 & $\mathrm{Xxxx}$ \\
\hline
\end{tabular}

Sumber : Hasil Analisa

Keterangan :

$\begin{array}{ll}\mathrm{X} & \text { : Sangat Kumuh } \\ \mathrm{XX} & \text { : Kumuh Berat } \\ \mathrm{XXX} & \text { : Kumuh Sedang } \\ \mathrm{XXXX} & \text { : Kumuh Ringan } \\ \mathrm{XXXXX} & \text { : Tidak Kumuh }\end{array}$

\section{KESIMPULAN}

Berdasarkan hasil pengolahan data dan analisis dalam penelitian ini, tingkat kekumuhan di Kelurahan Bhayangkara tergolong kumuh ringan karena prasarana yang harus ada sudah tersedia seperti fasilitas kesehatan, pendidikan, jaringan listrik, dan jaringan telekomunikasi. Dengan adanya sarana dan prasarana yang memadai dapat memudahkan penduduknya untuk beraktivitas sehari-hari. Semakin lengkap sarana dan prasarana yang tersedia maka semakin banyak pula orang yang berkeinginan bertempat tinggal di daerah tersebut.

\section{DAFTAR RUJUKAN}

[1] Abdulah, Hasan (2001). Startegi Pengendalian Tingkat Kekumuhan Kawasan Permukiman Nelayan Pada Desa Nangadhero Kota Mbay Kabupaten Nagekeo, ITB: Bandung

[2] Judohusodo, Siswono. Tumbuhnya Pemukiman Liar di Daerah Perkotaan. JIIS vol.1. Jakarta: PAU-IS-UI \& PT Gramedia, 1991.

[3] Komarudin. Menelusuri Pembangunan Perumahan dan Pemukiman. Jakarta: Yayasan REI - PT. Rakasindo, 1997.

[4] Kuswartojo, Tjuk (2005) Perumahan dan Permukiman di Indonesia. ITB: Bandung.

[5] Nazir, Moh. 2002. Metode Penelitian. Ghalia Indonesia. Ciawi - Bogor.

[6] Pontoh, Nia dan Kustiwan, Iwan. Pengantar Perencanaan Perkotaan. 2009. ITB Bandung.

[7] Sastra, Suparno. Marlin, E. 2007. Perencanaan dan Pengembangan Perumahan. Yogyakarta: Andi.

[8] Sugiyono. Statistika Untuk Penelitian. 2015. Alfabeta. Bandung.

[9] ...........Undang Undang Tata Ruang Republik Indonesia Nomor 26 Tahun 2007 Tentang Penataan Ruang dan rencana Tata Ruang Nasional

[10]...........Undang Undang Perumahan dan permukiman Republik Indonesia Nomor 1 Tahun 2011 tentang Perumahan dan kawasan permukiman

[11] ........... Undang Undang Nomor 32 Tahun 2009, Tentang Perlingdungan Pengelolaan Lingkungan Hidup. 